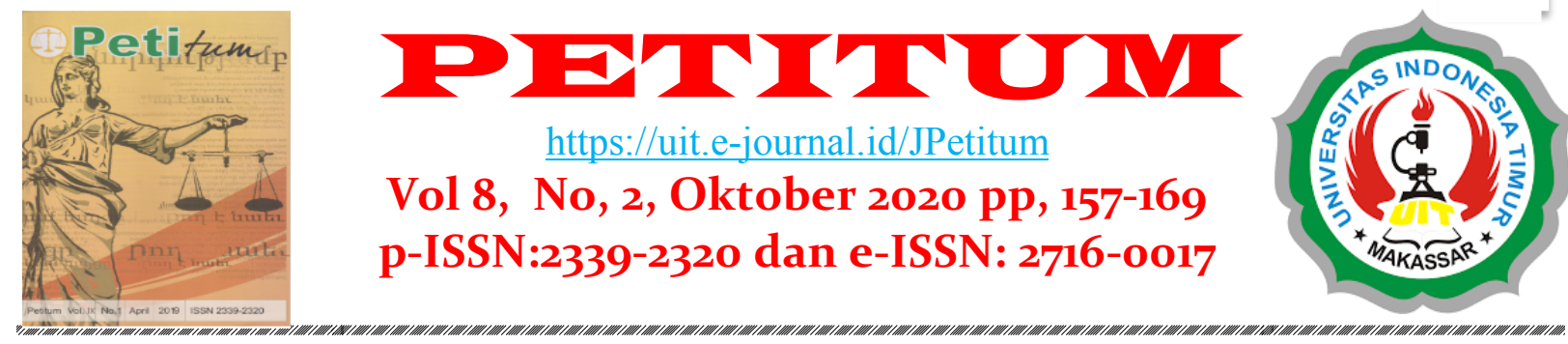

\title{
Tinjauan Hukum Islam Terhadap Pengelolaan Koperasi Kredit (Credit Union) Bina Usaha (BIMA) Kabupaten Sintang
}

\author{
Anggita Anggriana' \\ ${ }^{1}$ Fakultas Syariah, IAIN Pontianak, Email: tita.anggriana@gmail.com
}

\begin{abstract}
Artikel info

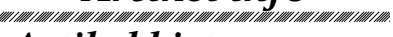
Artikel history:

Received; 27-07-2020

Revised: 19-10-2020

Published: 24-10-2020

ABSTRACT: The purpose of this study was conducted to answer the BIMA Sintang Credit Union management model that conforms or not with the values of Islamic law. The research method used is empirical normative to identify the BIMA Sintang Credit Union management model directly in the field connected with the conception related to cooperative management in Islamic law, then analyzed qualitatively and is descriptive. The results of the study revealed that the institutional credibility supported by the principle of equilibrium and fairness carried out by the Sintang BIMA Credit Union greatly influenced the preferences of Muslim communities in strengthening and managing the economy of the Sintang District community. This has proven to bring enormous benefits to agrarian-style people. Although there is an element of usury, the emergency conditions for the absence of Syariah-based credit unions are the basis of permissibility law for Muslim communities in Sintang District. The advice that needs to be given is that an Islamic credit union institution must be built immediately to support the economic aspects of an agrarian-style society.
\end{abstract}

ABSTRAK: Tujuan penelitian ini dilakukan untuk menjawab model pengelolaan Credit Union BIMA Sintang yang sudah sesuai atau tidak dengan nilai-nilai hukum Islam. Metode penelitian yang digunakan adalah normatif empiris guna mengidentifikasi model pengelolaan Credit Union BIMA Sintang secara langsung di lapangan dihubungkan dengan konsepsi terkait pengelolaan koperasi di dalam hukum Islam, kemudian dianalisis secara kualitatif dan bersifat deskriptif. Hasil penelitian mengungkapkan bahwa kredibilitas kelembagaan yang ditunjang dengan prinsip kesetimbangan dan keadilan yang dilaksanakan oleh Credit Union BIMA Sintang sangat mempengaruhi preferensi masyarakat muslim dalam penguatan dan pengelolaan perekonomian masyarakat Kabupaten Sintang. Hal tersebut terbukti mendatangkan maslahat yang sangat besar kepada masyarakat yang bercorak agraris. Meskipun terdapat unsur riba namun kondisi darurat atas belum adanya credit union berbasis syariah menjadi dasar hukum kebolehan bagi masyarakat muslim di Kabupaten Sintang. Saran yang perlu diberikan adalah perlu segera dibangun lembaga credit union syariah dalam menunjang aspek perekonomian masyarakat yang bercorak agraris.

\section{Kata Kunci:}

Koperasi Kredit; Mudharabah; Syirkah; Wadi'ah
Coresponden author:

Email: tita.anggriana@gmail.com artikel dengan akses terbuka dibawah lisensi CC BY 


\section{PENDAHULAN}

Keberadaan badan usaha koperasi di Indonesia memiliki peran sentral yang sangat strategis bagi penguatan ekonomi kerakyatan. Karakteristik koperasi didesain sebagai badan usaha yang mampu memacu pergerakan dan penguatan ekonomi pada skala usaha kecil menengah. Menurut Hatta, koperasi merupakan badan usaha bersama yang bergerak dalam bidang perekonomian, beranggotakan mereka yang umumnya berekonomi lemah, yang bergabung secara sukarela, berdasarkan persamaan hak dan kewajiban untuk melakukan suatu usaha yang bertujuan memenuhi kebutuhan-kebutuhan para anggotanya (Kurniawan, 2013). Oleh karena itu, koperasi menjadi wadah bagi para anggota untuk mendorong tumbuhnya berbagai macam usaha kecil menengah di tengah masyarakat yang sangat berdampak bagi peningkatan kesejahteraan bersama.

Dasar filosofis dibentuknya koperasi adalah sila kelima Pancasila yang merujuk pada konsep kesejahteraan rakyat. Bahwa kesetaraan dan pemenuhan hak-hak ekonomi di dalam kegiatan koperasi merupakan bentuk penjabaran keadilan sosial yang bertujuan pada upaya bersama demi mewujudkan kesejahteraan bersama. Sementara itu, dasar konstitusionalitasnya dapat dilihat di dalam Pasal 33 ayat (1) Undang-Undang Dasar Negara Republik Indonesia Tahun 1945 yang menyatakan bahwa "Perekonomian Indonesia disusun sebagai usaha bersama berdasar atas asas kekeluargaan".

Bahwa frasa "usaha bersama" merupakan konsepsi perekonomian yang dibangun dengan basis kemasyarakatan, bukan individual. Ekonomi tidak akan dapat berjalan dengan kuat manakala unsur masyarakat tidak saling menopang dan memperkuat kebersamaan. Kolektivitas masyarakat menjadi sumber daya bagi penguatan ekonomi kerakyatan. Oleh karenanya, di dalam tubuh koperasi terdapat karakteristik yang sesuai dengan struktur sosial masyarakat, kolektivitas masyarakat dalam bentuk gotong royong, prinsip saling tolong menolong, prinsip kekeluargaan dan secara transendental memiliki nilai religiusitas (Hadhikusuma, 2000).

Secara yuridis, keberadaan badan usaha koperasi diatur di dalam Undang-Undang Nomor 17 Tahun 2012 tentang Perkoperasian (UU Perkoperasian). Dalam membentuk badan usaha koperasi, terdapat berbagai macam jenis bentuk usaha koperasi, salah satunya adalah koperasi simpan pinjam sebagaimana diatur di dalam Pasal 88 sampai dengan Pasal 95 UU Perkoperasian. Bentuk kegiatan usahanya adalah penghimpunan dana anggotanya, pemberian kredit simpan pinjam, dan penempatan dana anggota kepada koperasi sekundernya.

Secara historis, kegiatan simpan pinjam merupakan embrio dari lahirnya konsep kelembagaan koperasi di Indonesia sehingga dapat dimaknai bahwa semangat awal pelembagaan koperasi adalah untuk memperkuat arus kegiatan pengelolaan simpan pinjam yang terstrukturisasi secara yuridis. Pada perkembangannya, koperasi simpan pinjam mengalami transformasi model yang salah satunya adalah koperasi kredit (Credit Union). Koperasi kredit adalah salah satu jenis koperasi yang termasuk dalam jenis koperasi jasa, yakni jasa keuangan. Koperasi kredit mempunyai karakteristik yang berbeda dengan model koperasi simpan pinjam lainnya.

Koperasi kredit adalah koperasi yang bergerak dalam usaha pembentukan modal melalui tabungan para anggota secara teratur dan terus menerus untuk kemudian 
dipinjamkan kepada para anggota dengan cara cepat, murah, mudah dan tepat demi tujuan produktif dan peningkatan kesejahteraan (Kaban, 2011). Unit-unit simpan pinjam dalam Koperasi Unit Desa (KUD), Kredit Serba Usaha (KSU), Koperasi Kredit (Credit Union), fakta konkrit seperti koperasi kredit Keling Kumang, Koperasi Kredit Bina Masyarakat, Koperasi Kredit Pancur Kasih, Koperasi Kredit Lantang Tipo masih ada lagi contoh lain misalnya Bank Koperasi Indonesia (Bukopin), Bank Koperasi Pasar, dan lain-lain.

Keberadaan koperasi kredit sangat membantu masyarakat dalam mengelola keuangan dan memanfaatkannya untuk kepentingan pengembangan modal usaha kecil menengah dan kebutuhan lainnya misalnya dana pendidikan bagi anak-anak, dana kesehatan dan kebutuhan lainnya (Ngebi, 2017). Khusus pada kegiatan peminjaman, koperasi kredit mengutamakan penyalurannya kepada para anggota dengan bunga yang relatif murah dalam kisaran dua belas persen pertahun. Jika dikemudian hari para anggota sudah tidak membutuhkan peminjaman dan kas dana relatif surplus, maka tidak menutup kemungkinan koperasi kredit membuka akses pinjaman kepada masyarakat yang tidak tergabung ke dalam anggota koperasi (Kasmir, 2013).

Pengembangan koperasi kredit tidak terlepas dari unsur masyarakat sebagai magnet utama keberlangsungannya di Indonesia. Secara garis besar, masyarakat muslim merupakan jumlah yang mayoritas di Indonesia dan sangat berperan dalam pengembangan ekonomi kerakyatan. Masyarakat muslim mulai menyadari arti pentingnya pengelolaan keuangan yang sesuai dengan nilai-nilai hukum Islam, khususnya di bidang ekonomi Islam. Masyarakat muslim mulai mengupayakan integralisasi nilai-nilai hukum Islam ke dalam aktivitas perekonomian di Indonesia. Integralisasi tersebut ditujukan tidak hanya demi kepentingan kesejahteraan semata, lebih dari itu ditujukan pada ketaatan terhadap konsep dan ajaran Islam (Bunga, 2017).

Proses transaksi keuangan dalam konsep ekonomi Islam harus dilandasi oleh aturan hukum Islam yang juga biasa disebut sebagai hukum ekonomi syariah. Pada konteks inilah suatu transaksi dibangun sebagai bentuk manifestasi terhadap ajaran Islam yang berorientasi pada keberkahan hidup dan ketaatan kepada sang Khaliq dan kesejahteraan bersama dalam konteks kehidupan bermasyarakat. Oleh karena itu dalam hukum ekonomi syariah mengenal konsep transaksi antara yang halal dan yang haram (Wiyonso, 2005).

Konsep tersebut memang tidak selamanya dilakukan dalam bentuk pendirian koperasi kredit berbasis syariah, namun kebiasaan masyarakat dalam mendirikan koperasi, khususnya koperasi kredit adalah mengupayakan bentuk pengelolaan keuangan koperasi kredit dengan berlandaskan semangat ekonomi kerakyatan dan juga internalisasi nilai-nilai hukum ekonomi syariah secara integral. Semangat atas konsep ekonomi kerakyatan ini mulai tumbuh subur di Indonesia, khususnya di Kalimantan Barat, salah satunya adalah Credit Union Bina Masyarakat Sintang (CU BIMA Sintang) yang terletak di Kabupaten Sintang.

Yang menarik dari keberadaan CU BIMA Sintang ini adalah pendiriannya dilakukan oleh keuskupan gereja katolik di Kabupaten Sintang dengan para pendiri yang terdiri dari para pastor dan anggota gereja. Proses pengelolaan dan pemberdayaan para anggota dikelola langsung atau disapih di bawah kendali gereja. Pada 
perkembangannya, para pendiri dan para anggota menyadari bahwa eksistensi $C U$ BIMA Sintang yang bersifat eksklusif tidak memiliki dampak pada kesejahteraan masyarakat di luar lingkungan gereja. Oleh karena itu, CU Sintang Bima kemudian memindahkan sekretariatan dari gereja ke luar gereja untuk memberikan akses yang luas kepada masyarakat agar dapat menjaring para anggota dan berperan dalam pembangunan ekonomi masyarakat di Kabupaten Sintang tanpa mengenal suku dan agama. Hingga kini per Maret 2020, jumlah anggota yang non katolik justru memiliki jumlah yang tidak lebih sedikit daripada yang katolik. Khusus bagi anggota yang beragama Islam telah mencapai 1.912 orang (Sintang, 2020).

Banyaknya anggota yang berasal dari umat muslim menandakan tingkat kepercayaan publik sangat tinggi terhadap CU BIMA Sintang. Mayoritas umat muslim di Kabupaten Sintang justru memberikan apresiasi atas kredibilitas dan akuntabilitas pengelolaan dana di CU BIMA Sintang sehingga sangat menarik untuk melihat model pengelolaan dana kredit CU BIMA Sintang yang sangat kredibel dalam membangun integritas namanya (branding) terhadap preferensi umat muslim di Kabupaten Sintang.

Meskipun demikian, muncul dilema mengenai kehalalan aktivitas ekonomi melalui koperasi kredit yang notabene berasal dari keuskupan gereja katolik. Banyaknya jumlah masyarakat muslim yang tergabung menjadi anggota CU BIMA Sintang pada dasarnya merupakan kebutuhan bagi aktivitas perekonomian masyarakat yang membutuhkan akses modal pembiayaan usaha yang sangat berdampak pada pertumbuhan ekonomi masyarakat. Namun disisi lain, masyarakat muslim terikat pada ajaran ketauhidan, khususnya dalam aktivitas muamalah yang sangat menekankan pada aspek kehalalan usaha dan menghindari adanya praktik riba. Taqiyuddin Al-Nabhani merupakan ulama yang tegas menolak koperasi masuk dalam aktivitas ekonomi masyarakat muslim. Menurutnya, koperasi merupakan perkara yang bathil karena bertentangan dengan hukum Islam (Hamzah, 2017).

Tentu fenomena maraknya masyarakat muslim yang tergabung dalam keanggotaan CU BIMA Sintang menjadi menarik untuk diteliti, khususnya bagaimana hukum Islam menjawab konteks tersebut. Oleh karena itu, penelitian ini dilakukan untuk menjawab model pengelolaan CU BIMA Sintang yang sudah sesuai atau tidak dengan nilai-nilai hukum Islam sehingga mampu menarik preferensi umat muslim di Kabupaten Sintang.

\section{METODE PENELITIAN}

Metode Penelitian hukum Islam yang digunakan adalah penelitian hukum Islam normatif empiris (applied law research) guna mengidentifikasi model pengelolaan CU BIMA Sintang secara langsung (law in action) di lapangan dihubungkan dengan konsepsi terkait pengelolaan koperasi di dalam hukum Islam (law in book) (Muhammad, 2004). Hasil penelitian dianalisis secara kualitatif dan bersifat deskriptif. Sumber data yang digunakan adalah data primer berupa data terkait $\mathrm{CU}$ BIMA Sintang yang dilakukan melalui observasi serta dokumentasi dan data sekunder yang diperoleh dari peraturan perundang-undangan, buku-buku dan hasil penelitian terkait. 


\section{HASIL DAN PEMBAHASAN}

\section{A. Memahami Koperasi Kredit dalam Hukum Islam}

Konsepsi awal keberadaan koperasi ditujukan pada pelembagaan mekanisme gotong royong suatu masyarakat dalam kehidupan ekonomi yang dalam hukum Islam disebut sebagai kegiatan muamalah. Kegiatan ekonomi berbasis gotong royong yang diinstitusionalisasikan ke dalam koperasi pada dasarnya merupakan bentuk internalisasi konsep tolong menolong di dalam Islam. Di dalam Al-Qur'an Surah Al-Maidah ayat 2 Allah SWT Berfirman, "Dan tolong menolonglah kamu dalam (mengerjakan) kebajikan dan taqwa, dan jangan tolong menolong dalam berbuat dosa dan permusuhan" (K. A. R. Indonesia, 2013).

Kegiatan muamalah sudah berjalan sejak zaman Nabi Muhammad SAW. Bahkan Beliau merupakan seorang pedagang bersama-sama dengan istrinya Siti Khadijah. Dalam konsep muamalah, terdapat kaidah fiqhiyyah furu'iyah yakni, "Pada dasarnya, segala bentuk muamalah boleh dilakukan, kecuali ada dalil yang mengharamkannya" (Djazuli, 2014). Dari kaidah ushul fikih tersebut dapat dimaknai bahwa konsep koperasi sama sekali tidak masuk kategori muamalah yang dilarang dikarenakan baik dalam Al-Qur'an maupun Hadis tidak dijumpai pelarangan terhadap lembaga koperasi.

Kaidah fighiyyah furu'iyah di atas memegang peranan yang sangat penting dalam menjawab berbagai macam masalah-masalah kontemporer dan digunakan oleh para ulama, khususnya Majelis Ulama Indonesia dalam menetapkan berbagai macam hukum yang berkaitan dengan aktivitas muamalah di Indonesia (Talhah, 2014).

Selain itu, pendirian lembaga koperasi dilakukan secara bersama-sama oleh para pendiri dan memiliki keanggotaan yang semua anggota tersebut mendapatkan hak dan kewajiban yang sama. Keberadaan koperasi dan para anggota dilakukan melalui suatu kontrak atau akad yang mendudukkan para pihak secara setara atau berimbang. Prinsip yang dibangun adalah prinsip keridhaan bersama. Dalam AlQur'an Surah An-Nisa ayat 29 Allah SWT Berfirman, "Wahai orang-orang yang beriman! Janganlah kamu saling memakan harta sesamamu dengan jalan yang batil (tidak benar), kecuali dalam perdagangan yang berlaku atas dasar suka sama suka di antara kamu" (K. A. R. Indonesia, 2013). Ayat tersebut menjelaskan bahwa dalam setiap aktivitas muamalah, harus didasari atas prinsip keridhaan atau kerelaan. Prinsip keridhaan juga dimaknai sebagai asas konsensualitas di dalam hukum perdata sebagai pijakan utama dalam suatu kontrak atau akad. Kesepakatan tidak akan terjadi manakala dalam prosesi negosiasi akad, dilakukan secara tidak berimbang. Oleh karena itu, menjadi sangat penting dalam setiap prosesi akad adalah proses kerelaan bersama yang dibangun di atas dasar kebebasan berkontrak yang mendudukkan para pihak ke dalam pihak yang seimbang dan saling menguntungkan satu sama lain agar diantara keduanya tercipta suatu akad yang mencirikan konsensualitas di antara mereka.

Konteks aktivitas perkoperasian, keridhaan dibangun atas dasar saling tolong menolong atau nilai gotong royong. Konsep ini jelas dibangun atas dasar kesetimbangan bersama demi memupuk solidaritas finansial dan penguatan ekonomi kerakyatan. Dari sini sudah jelas bahwa kedudukan suatu koperasi selain 
ditujukan sebagai bentuk pelembagaan kegiatan muamalah dengan konsep tolong menolong atau gotong royong juga proses kerjanya didasari atas prinsip keridhaan yang sifatnya halal. Di sini para ulama kemudian menggunakan pendekatan maqashid syariah sebagai pijakan utama dalam menentukan hukum koperasi di Indonesia. Imam Asy-Syatibi menjelaskan maqashid syariah sebagai tujuan kemaslahatan bersama dan suatu upaya untuk menghindari kemudaratan yang dihasilkan dari penerapan suatu hukum Islam (Asy-Syatibi, 1997).

Menurut (Nasutio, 2019) dalam perspektif maqashid syariah keberadaan koperasi ditujukan untuk mendatangkan kemaslahatan dalam bentuk pengembangan dan penguatan ekonomi kerakyatan, membangun solidaritas finansial serta mencegah kemudaratan bersama, artinya koperasi sudah sesuai dengan maqashid syariah yang berorientasi pada kemaslahatan perekonomian umat dan masyarakat kecil secara keseluruhan.

onteks maqashid syariah, terdapat empat poin penting yang memberikan nilai pada keberadaan koperasi bagi masyarakat muslim. Pertama, koperasi ditujukan untuk kesejahteraan bersama. Artinya, koperasi dibangun atas dasar prinsip kerja sama dan kebersamaan dalam mencapai kesejahteraan. Hal ini sesuai dengan konsep ta'wan (tolong menolong) dalam Islam. Kedua, koperasi mendatangkan keadilan distribusi. Keadilan distribusi merupakan konsep keadilan dalam Islam yang menekankan pada aspek keadilan sosial ekonomi sesuai dengan kinerjanya masing-masing. Ketiga, keadilan dan persaudaraan menyeluruh. Koperasi dibangun atas asas kekeluargaan diantara para anggotanya, hal ini sesuai dengan konsep ukhuwah dalam Islam. Keempat, kebebasan individu dalam konteks kesejahteraan sosial. Artinya setiap orang memiliki kebebasan dalam menjalankan usahanya sepanjang tidak bertentangan dengan nilai keislaman (Fikri et al., 2018)

Konsep muamalah, kedudukan koperasi disamakan dengan syirkah (perseroan atau perserikatan) atau syirkah ta'awuniyah (perseroan tolong menolong). Konsep syirkah diterima oleh para ulama baik ulama Malikiyah, ulama Syafi'iyah maupun ulama Hanafiyah karena kandungan hikmahnya yang sangat besar yakni pengembangan perekonomian dengan pembagian keuntungan dan rugi (Humaeroh, 2017).

Syirkah memiliki dua model yakni model kepemilikan (syirkah amlak) dan model kontrak (syirkah 'uqud). Pada model pertama, disebut kepemilikan dikarenakan suatu perseroan diperoleh langsung dari suatu perbuatan hukum bersegi satu tanpa melalui kontrak yang sifatnya bersegi dua, misalnya melalui wakaf, wasiat, hibah, dan warisan. Sedangkan pada model kedua, suatu perseroan lahir karena adanya kesepakatan atau kontrak antara dua pihak atau lebih (Yarmunida, 2014). Akad yang digunakan dalam keanggotaan koperasi adalah akad musyarakah yakni pencampuran modal antara koperasi dengan anggota koperasi dengan prinsip bagi hasil atau dalam dunia koperasi disebut sisa hasil usaha. Menurut Basir, musyarakah memiliki nilai pada proporsionalitas dan kesetimbangan dalam mendudukkan posisi para pihak di dalam akadnya. Kedua nilai tersebut sangat berperan dalam membangun aspek perekonomian masyarakat melalui fee based income (Wulandari \& Basir, 2020). 
Sebagai lembaga yang berperan dalam pengelolaan ekonomi kerakyatan, kegiatan usaha koperasi atau produk-produk yang secara umum ditawarkan adalah produk simpanan (funding) dan produk pinjaman atau pembiayaan (lending). Pada produk simpanan, akad yang digunakan adalah akad titipan (wadi'ah) yakni suatu kegiatan penitipan atau penyimpanan barang yang dilakukan oleh satu pihak kepada pihak lain yang dapat dimanfaatkan ataupun tidak dengan ketentuan pihak lain harus menjaga dan memeliharanya dan sewaktu-waktu pihak yang menitipkan dapat mengambilnya kembali (Ismail, 2014). Sementara itu pada produk pinjaman, akad yang digunakan adalah aqad utang (qardh) ataupun akad pembiayaan dalam bentuk skema bagi hasil baik mudharabah (ajib, 2013).

\section{B. Sejarah dan Kelembagaan CU BIMA Sintang}

Keberadaan koperasi kredit di Indonesia tidak dapat dilepaskan dari pengaruh Pastor Karl Arbicht (Arbicht Karim SJ) yang memperkenalkan konsep ini ke dalam dunia perkoperasian pada sekitar tahun 1970an di Indonesia. Keberadaan CU BIMA Sintang tidak terlepas dari pengaruh Arbicht Karim SJ, khususnya bagi pembentukan koperasi kredit di Kalimantan Barat (Sugiarto \& Alika, 2014).

Pendirian CU BIMA Sintang dipelopori oleh peran besar keuskupan di Kabupaten Sintang yang tergabung dalam Komisi Pengembangan Sosial Ekonomi (KPSE) dengan tujuan pengembangan dan pemberdayaan ekonomi masyarakat di Kabupaten Sintang. Untuk mencapai tujuan tersebut, KPSE kemudian sepakat membentuk suatu wadah koperasi kredit bernama CU BIMA Sintang pada tanggal 17 Agustus 1988 dengan terpilihnya salah satu pendiri yakni Bapak Paulus Jimbau sebagai ketua dan pendiri lainnya Bapak Agrianus sebagai manajer. Jumlah modal awal yang terkumpul adalah sebesar Rp. 128.000,- dengan jumlah anggota yang masih sangat sedikit.

Pada awal perkembangannya, jumlah sumber daya manusia yang sedikit dan pengetahuan serta kemampuan manajerial yang belum memadai maka pengelolaan CU BIMA Sintang dibantu oleh Pastor Yosep van Lier. Sementara itu, Bapak Agrianus diberi tugas kuliah di STIE Perbanas Jakarta sebagai bentuk kesadaran terhadap pengembangan sumber daya manusia untuk menunjang pengembangan pengelolaan kelembagaan CU BIMA Sintang oleh orang-orang yang kompeten.

CU BIMA Sintang mulai terdaftar sebagai badan hukum sejak tanggal 24 Januari 1995 dengan Nomor 1555/BH/X, tanggal 24 Januari 1995. Misi utama dari CU BIMA Sintang adalah untuk melayani masyarakat pedalaman dan memberantas ketidakberdayaan dalam bidang ekonomi dan keuangan. Namun dalam perkembangannya, mengingat jumlah anggota yang kini mencapai 32.021 orang maka CU BIMA Sintang melakukan pembaruan terkait visi misi kelembagaan. Visi CU BIMA Sintang adalah "Menjadi credit union yang dimiliki oleh anggota" dan misi CU BIMA Sintang adalah "Menyediakan pelayanan keuangan yang berkelanjutan agar mampu meningkatkan kualitas hidup anggota".

Selanjutnya nilai-nilai inti yang dianut oleh CU BIMA Sintang adalah (1) Behaviour/perilaku, yakni memiliki perilaku yang terpuji terhadap anggota, sesama karyawan, pengurus dan pengawas dalam memberikan pelayanan yang terbaik bagi lembaga CU BIMA Sintang. (2) Integrity/konsisten, yakni bertindak konsisten dan menjaga keteguhan hati dalam menjunjung tinggi nilai-nilai lembaga $C U$ BIMA 
Sintang. (3) Measurable/dapat diukur, yakni seluruh kegiatan pekerjaan di lembaga CU BIMA Sintang dapat diukur dengan tepat sesuai dengan target pencapaian lembaga. (4) Added value/nilai tambah, yakni memberikan nilai tambah bagi anggota, karyawan dan keluarga serta lingkungan masyarakat.

Perkembangan yang semakin pesat dengan jumlah anggota yang tumbuh signifikan memberi dampak pada pertumbuhan aset. Pada tahun 1988 total aset CU BIMA Sintang sebesar Rp. 471.000,- jumlah anggota sebanyak 20 orang. Kemudian aset CU BIMA Sintang terus berkembang hingga terakhir pada tahun 2019 total aset CU BIMA Sintang sudah mencapai Rp. 363.993.950.560,- dengan jumlah anggota yang naik sebanyak 32.021 orang.

\section{Gambar 1. Struktur Organisasi CU BIMA Sintang}

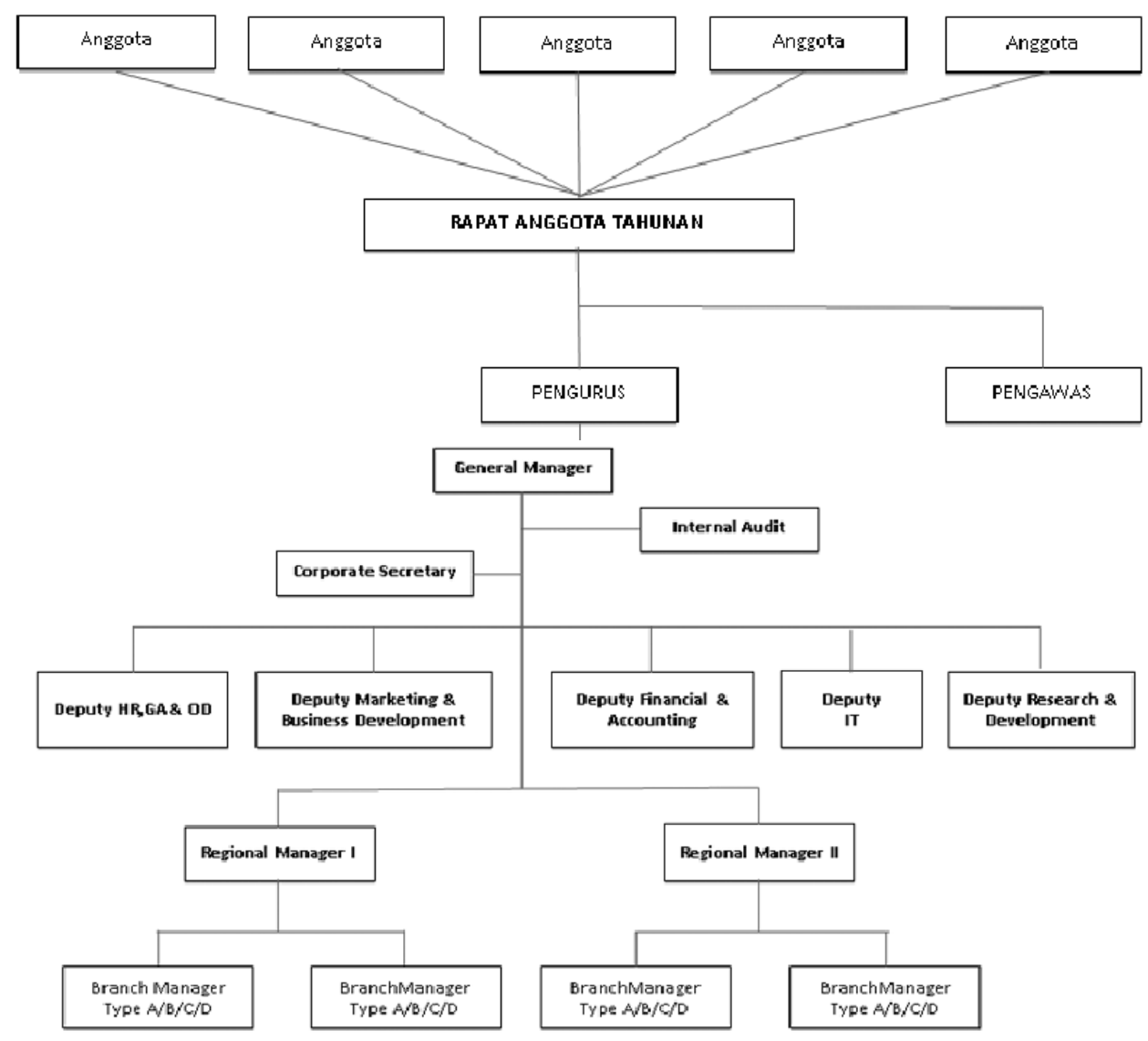

Saat ini $C U$ BIMA Sintang diketuai oleh Bapak Adrianus Lawi sebagai ketua dan Bapak Antonius sebagai wakil ketua. Di awal sudah disebutkan bahwa jumlah anggota $C U$ BIMA Sintang sebanyak 32.021 orang. Namun, jumlah tersebut oleh para pengurus dianggap belum mencapai target yang diinginkan yakni sebanyak 35.269 orang, akan tetapi, dilihat dari realisasi capaian jumlah anggota sudah mencapai presentasi 90,79\%. Beberapa produk yang dimiliki oleh CU BIMA Sintang adalah Simpanan Masa Tua, Simpanan Perkebunan, Tabungan Beasiswa, Tabungan Anak Sekolah, Simpanan Taktis, Simpanan Sukarela, Simpanan Wajib, Simpanan Bunga Harian (Sibuhar) dan Simpanan Pokok. Selain produk simpanan, CU BIMA Sintang juga memiliki produk pinjaman antara lain Pinjaman Kelompok, Pinjaman Perkebunan, 
Pinjaman Jangka Pendek, Pinjaman Mikro Anggota, dan Pinjaman Perumahan (Sintang, 2020).

\section{Pengelolaan CU BIMA Sintang Ditinjau dari Hukum Islam}

CU BIMA Sintang yang didirikan dan dikelola oleh pihak keuskupan memiliki jumlah anggota yang cukup banyak berasal dari masyarakat muslim. Kredibilitas pengelolaan, kejelasan akad dan nilai kemaslahatan dirasakan memiliki dampak yang sangat besar bagi perkembangan dan penguatan ekonomi masyarakat. Secara musyarakah, untuk menjadi anggota CU BIMA Sintang persyaratan yang harus dipenuhi yakni (1) warga negara Indonesia, (2) memiliki kecakapan hukum, (3) memiliki kesamaan kepentingan ekonomi, (4) menyetujui isi AD/ART CU BIMA Sintang, (5) menyetor biaya administrasi dan syarat keuangan yakni Simpanan Wajib, Simpanan Pokok dan Simpanan Sejahtera Anggota, (6) berdomisili di wilayah kerja CU BIMA Sintang, dan (7) bersedia mengisi formulir menjadi anggota (Sintang, 2020).

Dari persyaratan di atas, hal pertama yang harus dilakukan oleh calon anggota terlebih dahulu ialah kesatuan pemahaman baik dari segi hukum dan kepentingan ekonomi bersama, kemudian memahami isi dari AD/ART sebagai konstitusi bersama antara koperasi dan para anggota. Jika literasi dan pemahaman terhadap CU BIMA Sintang telah dipahami dengan baik maka calon anggota dapat bergabung dengan syarat keuangan berupa menyerahkan setoran yang akan dimasukkan ke dalam simpanan sebagaimana yang diwajibkan sebagai syarat keanggotaan. Jika telah terdaftar, para anggota memiliki hak dan kewajiban yang sama atau setara. Di sini para anggota dianggap sebagai mitra yang memiliki kesamaan persepsi atas konsep pereonomian bersama yang ditujukan untuk mencapai kesejahteraan para anggota secara setimbang.

Proporsionalitas dan kesetimbangan tersebut dibangun atas prinsip kekeluargaan dan kemitraan dengan setiap tahunnya akan dihitung besaran presentase sisa hasil usaha yang akan dibagikan kepada para anggota. Apa yang dirasakan oleh para anggota ialah nilai kemaslahatan yang sangat besar khususnya bagi penguatan ekonomi kerakyatan di wilayah kerja CU BIMA Sintang yang dirasakan secara nyata. Oleh karena itu, jika melihat pada perspektif maqashid syariah, proses akad dan berjalannya akad dibangun atas dasar yang sama dengan skema musyarakah.

CU BIMA Sintang memiliki banyak produk namun hanya terkait pada dua bentuk, yakni pinjaman (lending) dan simpanan (funding). Pada produk pinjaman jika ditinjau dari segi mudharabah, akad kerjasama antara dua pihak dalam usaha bisnis dapat digambarkan bahwa pihak koperasi berkedudukan sebagai penyalur modal (shahibul maal) sedangkan anggota yang mengajukan pinjaman berkedudukan sebagai pengelola modal (mudharib). Keuntungan dari usaha bisnis tersebut dibagi menurut kesepakatan yang dituangkan ketika akad dalam bentuk nisbah bagi hasil.

Jika dilihat dari rukun mudharabah ada 5 (lima), yaitu dua orang yang berakad, adanya modal, adanya kegiatan pengelolaan modal, adanya keuntungan (nisbah), serta ijab kabul. Sementara itu pada praktiknya, dalam produk pinjaman, terdapat beberapa macam pinjaman yang dimiliki oleh CU BIMA Sintang, yakni pinjaman perkebunan, pinjaman kelompok, pinjaman mikro anggota, pinjaman perumahan dan pinjaman jangka pendek. Kesemuanya produk pinjaman tersebut merupakan 
ranah investasi yang masuk kategori mudharabah akan tetapi, produk-produk pinjaman tersebut menetapkan bunga sebesar $1 \%$ (satu persen) yang tentu saja bersinggungan dengan riba.

Selain pinjaman, produk di bidang simpanan juga sebagian memiliki skema yang sama dengan mudharabah, misalnya Simpanan Masa Tua, Simpanan Perkebunan, Tabungan Beasiswa, dan Tabungan Anak Sekolah. Namun, skema di dalamnya bergantung pada suku bunga yang masing-masing produk memiliki skema bungan yang berbeda. Hal ini tentu saja akan sangat bergesekan dengan konsep riba. Sementara itu, jumlah masyarakat muslim yang menjadi anggota dan menggunakan produk-produk CU BIMA Sintang sangat banyak yakni 1.912 orang.

Dalam Al-Qur'an Surah Al-An'am ayat 119 Allah SWT Berfirman, "Dan mengapa kamu tidak mau memakan dari apa (daging hewan) yang (ketika disembelih) disebut nama Allah, padahal Allah telah menjelaskan kepadamu apa yang diharamkan-Nya kepadamu, kecuali jika kamu dalam keadaan terpaksa..." (K. A. R. Indonesia, 2013). Meskipun teks ayat tersebut ditujukan kepada makanan yang haram namun, secara kontekstual konsep pengharaman yang telah ditentukan oleh Allah SWT dimaknai secara umum yakni keharaman yang jelas telah ditetapkan di dalam Al-Qur'an dan keharaman tersebut dapat dikecualikan dalam keadaan yang darurat.

Dalam konteks koperasi, ditinjau dari hukum Islam maka kedaruratan yang dimaksud sepanjang dapat dimaknai ketiadaan koperasi kredit berbasis syariah di Kabupaten Sintang. Berdasarkan data koperasi di laman data koperasi yang terdaftar di Kementerian Koperasi dan Usaha Kecil dan Menengah, dari total 258 lembaga koperasi di Kabupaten Sintang, terdapat 2 lembaga koperasi berbasis syariah yakni KSP Hikmah yang terletak di Kecamatan Sintang dan KSP Al-Barokah yang terletak di Kecamatan Binjai Hulu yang sama-sama terdaftar di tahun 2013 (K. K. dan U. K. dan M. R. Indonesia, 2020).

Meskipun sejak tahun 2013 sudah ada koperasi berbasis syariah di Kabupaten Sintang namun, bukan merupakan koperasi kredit sebagaimana yang menjadi keunggulan CU BIMA Sintang. Peran vital dari CU BIMA Sintang bagi masyarakat adalah penguatan perekonomian bagi masyarakat kecil yang mayoritas masyarakat di Kabupaten Sintang memiliki mata pencaharian sebagai petani sawit atau berkebun. Pengelolaan lahan pertanian atau perkebunan merupakan keunggulan masyarakat sekitar yang perlu diperkuat dari segi permodalan dan pengelolaan keuangan secara berimbang dan adil. Sementara itu pada praktiknya, CU BIMA Sintang menerapkan manajemen pengelolaan yang baik, menerapkan prinsip kesetimbangan dan keadilan sehingga kredibilitasnya sangat mempengaruhi preferensi masyarakat muslim di Kabupaten Sintang. Oleh karena itu, secara maqashi syariah dan dari sisi kedaruratan, keberadaan CU BIMA Sintang merupakan elan vital yang mampu memperkuat taraf hidup dan kesejahteraaan masyarakat kecil menengah khususnya dalam mempertahankan kelangsungan hidup dan pelestarian sumber daya alam.

Selain mudharabah, CU BIMA Sintang juga menerapkan wadi'ah dalam bentuk Simpanan Pokok dan Simpanan Wajib. Jika dilihat dari rukun wadi'ah ada 3 (tiga), yakni adanya barang yang dititipkan, orang yang menitipkan (calon dan anggota koperasi) beserta yang menerima titipan (koperasi), dan ijab kabul. Sementara itu dalam praktiknya rukun wadi'ah yang pertama yaitu harus ada barang yang 
dititipkan dalam hal ini diwujudkan dalam bentuk uang berupa Simpanan Pokok dan Simpanan Wajib yang dititipkan oleh calon anggota dan anggota koperasi kepada pihak koperasi sesuai dengan ijab kabul berupa persetujuan diawal antara calon anggota dengan koperasi. Meskipun demikian, keberadaan bunga berlaku hukum yang sama dengan skema mudharabah di atas yakni kondisi darurat dan perspektif maqashid syariah yang harus dilihat secara holistik mendatangkan kemaslahatan bagi masyarakat di sekitar Kabupaten Sintang.

\section{KESIMPULAN}

Keberadaan CU BIMA Sintang yang berada di bawah keuskupan Sintang telah memberikan pengaruh yang sangat besar kepada preferensi masyarakat muslim di Kabupaten Sintang dalam memilih keanggotaan koperasi kredit. Kredibilitas kelembagaan ditunjang dengan prinsip kesetimbangan dan keadilan menjadi nilai berharga sebagai elan vital bagi masyarakat Kabupaten Sintang dalam menjalankan roda perekonomian. CU BIMA Sintang berperan dalam pengembangan, pengelolaan dan penguatan perekonomian rakyat di Kabupaten Sintang sehingga sangat besar dalam mendatangkan kemaslahatan sebagaimana prinsip maqashi syariah. Memang tidak dapat dipungkiri bahwa produk-produk yang ditawarkan memiliki skema bunga namun, kondisi darurat atas ketiadaan koperasi kredit berbasis syariah juga mempengaruhi hukum kebolehan bagi masyarakat muslim di Kabupaten Sintang untuk menjadi anggota dan menggunakan produk-produk yang ditawarkan oleh $\mathrm{CU}$ BIMA Sintang.

\section{SARAN}

Diharapkan Majelis Ulama Indonesia (MUI) memperhatikan besarnya kebutuhan masyarakat kecil di Kabupaten Sintang terhadap eksistensi lembaga koperasi sehingga mengupayakan agar di Kabupaten Sintang segera berdiri koperasi kredit berbasis syariah sebagai koperasi kredit yang tidak hanya berperan dalam memperkuat perekonomian rakyat juga memberikan keberkahan dalam setiap aktivitas pengeloaan keuangan dan modal usaha yang disandari pada akad mudharabah dan wadi'ah. 


\section{DAFTAR PUSTAKA}

\section{Buku/Jurnal/Makalah}

Afif, M. (2014). Tabungan: Implementasi Akad Wadi'ah atau Qard? (Kajian Praktik Wadiah di Perbankan Indonesia). Jurnal Hukum Islam, 12(2), 251-264. https://doi.org/https://doi.org/10.28918/jhi.vii1.556

Ajib, G. (2013). Bunga Pinjaman dalam Perspektif Keadilan (Studi Kasus Bunga Pinjaman di KPRI Nusantara IAIN Walisongo). Economica: Jurnal Ekonomi Islam, $\quad 4(1), \quad 1-32$. https://doi.org/http://dx.doi.org/10.21580/economica.2013.4.1.688

Asy-Syatibi. (1997). Al-Muwfaqat fi Usul asy-Syari'ah. Dar Al-Kutub Al-Ilmiyyah.

Bunga, M. R. A. (2017). Tinjauan Hukum Islam Terhadap Pengelolaan Dana Simpan Pinjam di Serikat Takaful Guru Damrong Wittaya School (Bannangseta Yala Thailand Selatan). Universitas Muhammadiyah Surakarta.

Djazuli, A. (2014). Kaidah-Kaidah Fiqih. Prenadamedia Group.

Fikri, A. L. R., Yasin, M., \& Jupri, A. (2018). Konsep Pengelolaan Koperasi Pesantren untuk Kesejahteraan Ekonomi Masyarakat: Telaah Surah Al-Hasyr Ayat 7. AlMaslahah, 14(1), 91-112. https://doi.org/https://doi.org/10.24260/almaslahah.v14i1.1004

Hadhikusuma, R. T. S. R. (200o). Hukum Koperasi Indonesia. Raja Grafindo Persada.

Hamzah, I. (2017). Koperasi dalam Perspektif Hukum Islam (Telaah Kritis Pemikiran Hukum Islam Taqiyyuddin al-Nabhani). Al-Manahij: Jurnal Kajian Hukum Islam, 11(1), 103-112. https://doi.org/https://doi.org/10.24090/mnh.v11i1.1272

Humaeroh. (2017). Eksistensi Syirkah Ta'awuniyah dalam Perspektif Hukum Islam. Muamalatuna: Jurnal Hukum Ekonomi Syariah, 9(2), 20-33.

Indonesia, K. A. R. (2013). Mushaf Al-Qur'an Tajwid Warna E Terjemah Tanpa Takwil Asma Wa Sifat. CV. Albarkah Media.

Indonesia, K. K. dan U. K. dan M. R. (2020). Data Koperasi Kabupaten Sintang. Kementerian Koperasi Dan Usaha Kecil Dan Menengah Republik Indonesia.

Kaban, M. S. (2011). Pemanfaatan Modal Sosial dalam Credit Union (Studi Deskriptif Mengenai Kopdit/CU Cinta Kasih di Pulo Brayan, Medan). Universitas Sumatera Utara.

Kasmir. (2013). Bank dan Lembaga Keuangan Lainnya. Raja Grafindo Persada.

Kurniawan, I. G. H. (2013). Tindakan Koperasi Simpan Pinjam yang Mengakibatkan Perbuatan Tindak Pidana. LexJurnalica, 10(1), 1-7.

Muhammad, A. (2004). Hukum dan Penelitian Hukum. Citra Aditya Bhakti.

Nasution, A. I. (2019). Pendekatan Maqashid Al-Syari'ah dalam Praktik Pembiayaan di Koperasi Peternak Sapi Bandung Utara (KPSBU) Lembang. Asy-Syari'ah, 21(1), 31-38. https://doi.org/10.15575/as.v21i1.4036

Ngebi, S. (2017). Pertanggungjawaban Pengurus Koperasi dalam Pengembangan Jasa Keuangan Guna Menghadapi Persaingan Bisnis: Koordinasi Antar Manager 
dengan Pengurus dalam Mensejahterakan Anggota. Jurnal Nestor Magister Hukum, 1(1), 1-38.

Sintang, C. U. B. (2020). Data Kelembagaan CU BIMA Sintang (2 Maret 2020).

Sugiarto, B. A. T., \& Alika, C. L. (2014). Tinjauan Historis dan Filosofis Terhadap PrinsipPrinsip Koperasi dan Credit Union.

Talhah. (2014). Kaidah Fiqhiyah Furu'iyah: Penerapannya Pada Isu Kontemporer. Tahkim: Jurnal Hukum Dan Syariah, 10(1), 67-88. https://doi.org/http://dx.doi.org/10.33477/thk.v1oi1.64

Wiyonso, S. (2005). Cara Mudah Memahami Akuntansi Perbankan Syariah. Gramedia Pustaka Utama.

Wulandari, A. S. R., \& Basir, A. (2020). Penerapan Prinsip Bagi Hasil Pada Pembiayaan di Bank Syariah Menurut Undang-Undang Perbankan Syariah. Khatulistiwa Law Review, 1(1), 61-76.

Yarmunida, M. (2014). Eksistensi Syirkah kontemporer. Jurnal Ilmiah Mizani: Wacana Hukum, Ekonomi Dan Keagamaan, 1(2). https://doi.org/http://dx.doi.org/10.2930o/mzn.vii2.6o 